\title{
Debt Financing and Firm performance: An Analysis of Securities Commission of Malaysia 2013 Revised Shariah Approved Firms Screening Method
}

Nurshamimitul Ezza Ramli, Gairuzazmi M Ghani, Razali Haron, Norazizan Che Embi ${ }^{2}$

\author{
${ }^{1}$ Universiti Sains Islam Malaysia \\ ${ }^{2}$ International Islamic University Malaysia
IIUM Institute of Islamic Banking and Finance
}

\begin{abstract}
:
This study aims to assess the impact of the revised Shariah approved firms screening method in relation to the levels of debt and the Shariah-approved firms' performance introduced by the Securities Commission (SC) of Malaysia in 2013. The period of the study is 2000 to 2014. Panel regressions were employed to examine the impact for the firms that are consistently Shariahapproved as determined by the SC of Malaysia. The regression result indicates a non-monotone association between Shariah-approved firms' performance and debt levels. The optimum level of debt, however, is much higher than the $33 \%$ benchmark set by SC. Therefore, it can be concluded that the 2013 revised Shariah- approved firms screening method, which introduced the $33 \%$ debt ratio benchmark, did not improve the performance of Shariah-approved firms for the period studied. Nevertheless, since the observations are only until 2014, it is possible that the observations might not have captured the true impact of the change.
\end{abstract}

Keywords: Debt financing, Firm performance, Shariah-approved firms, Shariah screening method, Optimum debt level.

Acknowledgement: This study received funding from the Ministry of Higher Education (MOHE) Malaysia under Fundamental Research Grant Scheme FRGS15-233-0474.

\section{Introduction}

Securities Commission (SC) of Malaysia revised its Shariah approved firm 
screening method in November 2013. The revision of the screening method is consistent with SC's objective to internationalise and widen market connectivity and participation as stated in the Capital Market Master Plan 2 (CMP2). With the revision, a publicly listed firm in Bursa, Malaysia has to satisfy the $33 \%$ benchmark for both debt and cash ratio, among others, if the firm is to be classified as a Shariah approved firm. The revised Shariah screening method is consistent with many Shariah indexes, including Global Shariah index, Financial Times Stock Exchange Shariah index, and Dow Jones Islamic Index (Ho, 2015). The revision was expected to influence the performance of Shariah approved firms and indexes as the capital structure has been shown to affect the firms' performance (Berger and Patti, 2006).

Many studies have tested different theories that explain the association between capital structure and firm performance. The theories include trade-off theory (TOT), pecking order theory (POT), agency theory and market timing theory. However, studies do not show agreement on what constitutes an optimal capital structure or the best debt to equity ratio that will maximise the value of a firm. TOT postulates a positive relationship between the value of a firm and the amount of debt, but after a certain threshold level, additional debt taken may impact a firm's performance negatively. The TOT, however, does not indicate the threshold debt level at which this happens. Similarly, POT, which proposes preference ordering of financing, does not specify the ordering. Empirically, the studies on optimal capital structure have shown mixed findings and where thresholds exist, the level varies (Lin and Chang, 2011; Ahmad and Abdullah, 2013). As such, this study aims to ascertain the potential effects of 2013 revised Shariah approved firms screening method on Shariah approved firms' performance and consequently Shariah approved indexes in Malaysia. For this study, only those firms are chosen that are consistently Shariah-approved based on the SC's guideline for the period 2000 until 2014. The sectors included were (i) construction, (ii) consumer, (iii) industrial, (iv)plantation, (v) property, (v) technology, (vi) trading, and (vii) services.

\subsection{Shariah Approved Firms and Malaysian Capital Market}

Activities of capital markets in Malaysia are governed by the SC which was enacted based on the Securities Commission Act 1993. SC is a self-funded statutory body that reports directly to the Minister of Finance. It was empowered to investigate capital market activities and enforce acts that are related to the capital markets. SC is mandated to "promote and maintain fair, efficient, secure and transparent securities and derivative markets and to facilitate the orderly development of an innovative and competitive capital 
market" . Malaysian capital market system is governed by the (i) Companies Act 1965, (ii) Offshore Companies Act 1990, (iii) Labuan Offshore Securities Industry Act 1995, (iv) Capital Markets and Services (Amendment) Act 2015, (v) Securities Commission (Amendment) Act 2015 for ensuring good governance and efficiency of the markets.

Malaysian stock market has a unique structure. It includes both nonShariah and Shariah-approved firms and they are traded in parallel through two trading platforms namely the Main Market and the ACE Market. Both of the markets provide an investment opportunity for firms to acquire capital for business expansion; however, where the Main Market focuses on wellestablished firms, the ACE market targets start-up firms. In addition, the listing requirements for ACE market have a less rigorous relative to the Main Market.

Malaysia's capital market is more developed and structured as compared to other emerging capital markets in Asia Pacific. Regulatory enhancement, streamlining, consolidating and restructuring efforts have been developed to create a fair and more efficient capital market. For example, the introduction of the Capital Market Master Plan 1 (CMP1) in 2001 provided a comprehensive plan and strategy for growth that guided Malaysia's capital market during the 10-year period from 2001 to 2010. CMP2 was established in April 2011, following CMP1 for another 10 years plan. With the introduction of CMP2, Malaysia's capital market is expected to expand and grow to a more diversified and innovative environment supported by a governance strategy to enhance its soundness and confidence. In order to realise the aspirations of CMP2, several growth strategies have been developed which comprise the promotion of capital formation, deepening liquidity and risk intermediation, expansion of intermediation efficiency and scope, enabling internationalisation and capacity building, and enhancement of informational infrastructure (Securities Commission, 2011).

Securities Commission Shariah Advisory Council (SAC) advises on the criteria for Shariah approved firm and is responsible to ensure whether a firm complies with Shariah principles. Several criteria and benchmarks have been developed qualitatively and quantitatively to access the Shariah status of a firm. However, before proceeding to the qualitative and quantitative screening, the firm's core activities must not be non-permissible. These non-permissible

\footnotetext{
${ }^{1}$ www.sc.com.my
} 
activities include riba based financial services and related activities, conventional insurance, gambling and gaming activities, entertainment related activities that are non-Shariah compliant; production and/or sale of tobaccorelated goods, stock broking of non-Shariah compliant securities, and other non-allowed activities under the Shariah. A firm, whose main activities are nonpermissible from Shariah perspective, will not be Shariah-approved, and there will be no further assessment. However, the mixed-income firms are assessed both quantitatively and qualitatively. A mixed-income firm is a firm wherein the main activity is permissible, although its subsidiaries are involved in nonpermissible activities.

Qualitative screening requires a firm to have a good public image. Quantitatively, there are two benchmarks that need to be fulfilled for a firm to be Shariah approved which include activity and financial ratios.

The activity ratio benchmark examines the relative amount of the income realised by a firm from activities that are not allowed by the Shariah. The levels of income from these sources are equated with the firm's revenue and profit before tax (Securities Commission, 2011). Compared to the pre-2013 activity and the benchmark which include four different percentages for income from non-permissible activities, the 2013 revised method includes only two different percentages- the $5 \%$ and $20 \%$ benchmarks which are given to different types of business activities. The $10 \%$ benchmark that was previously adopted has been tightened to a $5 \%$ benchmark, while the $25 \%$ benchmark has been tightened to a $20 \%$ benchmark. In addition, two types of financial ratios namely the ratio of total cash or cash equivalent to total assets (cash ratio) and the ratio of total debt to total assets (debt ratio) are added. A firm that is considered as Shariah approved, will have a level of non-permissible income that is no higher than the specified benchmark. For a firm to be considered as Shariah-approved, the ratios must be below 33\%. However, only the conventional debt is counted in the leverage ratio, hence Murabaha or Ijarah are not included as debt.

A firm needs to fulfil the financial ratio and activity benchmarks. If neither of the benchmarks is fulfilled, the firm will not be considered as Shariah-approved. Table 1 summarises the comparison between pre-2013 Shariah screening method and the 2013 revised Shariah screening method. 
Table 1.1: Pre-2013 and 2013 Revised Shariah Screening Methodology

\begin{tabular}{|c|c|c|}
\hline & $\begin{array}{l}\text { Pre-2013 Shariah screening } \\
\text { methodology }\end{array}$ & $\begin{array}{l}2013 \quad \text { Revised Shariah } \\
\text { screening methodology }\end{array}$ \\
\hline $\begin{array}{l}\text { Qualitative } \\
\text { screening }\end{array}$ & $\begin{array}{l}\text { a) The firm must have } \\
\text { good public perception and } \\
\text { image } \\
\text { b) The main activities of } \\
\text { the firm are essential and } \\
\text { acknowledged as a maslahah } \\
\text { to the Muslim ummah. }\end{array}$ & $\begin{array}{l}\text { a) The firm must have } \\
\text { good public perception and } \\
\text { image }\end{array}$ \\
\hline $\begin{array}{l}\text { Activity } \\
\text { benchmark }\end{array}$ & $\begin{array}{l}\text { a) Income from prohibited } \\
\text { activities } \\
\text { Group revenue } \\
\text { and } \\
\text { b) Income from prohibited } \\
\text { activities } \\
\text { Group profit before tax } \\
\text { This calculation cannot } \\
\text { exceed the following } \\
\text { benchmark: } \\
\text { a) } 5 \% \\
\text { b) } 10 \% \\
\text { c) } 20 \% \\
\text { d) } 25 \%\end{array}$ & $\begin{array}{l}\text { a) Income from prohibited } \\
\text { activities } \\
\text { Group revenue } \\
\text { and } \\
\text { b) Income from prohibited } \\
\text { activities } \\
\text { Group profit before tax } \\
\text { This calculation cannot } \\
\text { exceed the following } \\
\text { benchmark: } \\
\text { a) } 5 \% \\
\text { The previous 10\% benchmark } \\
\text { is tightened to the } 5 \% \\
\text { benchmark. } \\
\text { b) 20\% } \\
\text { The previous 25\% benchmark } \\
\text { is tightened to the 20\% } \\
\text { benchmark. }\end{array}$ \\
\hline \multirow[t]{2}{*}{$\begin{array}{l}\text { Financial } \\
\text { ratio } \\
\text { benchmark }\end{array}$} & NA & $\begin{array}{l}\text { a) De tbrat oi } \\
\text { (Debt/Total assets) } \\
\text { b) Cash ratio } \\
\text { (Cash/Total assets) }\end{array}$ \\
\hline & & $\begin{array}{l}\text { Both ratios cannot exceed } \\
\text { the } 33 \% \text { benchmark }\end{array}$ \\
\hline
\end{tabular}

Notes: $5 \%$ benchmark measures firm activities that are clearly prohibited. 
$10 \%$ benchmark measures firm activities that involve the element of umum balwa.

$20 \%$ benchmark measures activities from rental payments from Shariah noncompliant activities.

$25 \%$ benchmark measures firm activities that are generally permissible according to Shariah and that have an element of maslahah to the public, but which contain elements that may affect their Shariah status.

Source: Securities Commission (2013)

Compared to the other leading indexes of the world, the SC Shariah screening method prior to 2013 was regarded as flexible and liberal (Pok, 2012). The revised Shariah screening method reduced Bursa Malaysia's Shariah-approved firms from 817 stocks in 2012 to 653 in 2013 and 673 in 2014. The new screening practices are consistent with other Islamic Index screening methods recognised worldwide. The introduction of the revised Shariah screening method assist in achieving the CMP2's objectives which include improving the quantity and quality of Shariah-compliant equities, increasing foreign Islamic funds inflow into Malaysia, and improving the investment management segments (Securities Commission Malaysia, 2013). In December 2014, 673 stocks had been approved as Shariah-approved stocks by the SAC, representing $74 \%$ of the 905 total stocks traded in Bursa, Malaysia at the end of 2014. As of December 2014, Shariah-approved firms held about $61.3 \%$ of the market capitalization and worth around RM 1,012.14 billion.

\subsection{Firm Performance and Capital Structure}

Following the traditional theory of capital structure, the optimisation of weighted average cost of capital (WACC) will lead to an optimal amount of capital, and consequently market value. However, Modigliani and Miller (1958) argued that capital structure is not relevant to explain a firm's performance; hence the question on the best debt to equity ratio does not arise. The irrelevance of the capital structure, however, assumes the perfect capital markets, which in many instances is not true (Arshad, 2016). Thus, a number of theories have emerged and relaxed the perfect capital markets assumption.

The TOT postulates that in deciding on the best debt to equity ratio, a firm will take into account the debt and equity financing costs and benefits. The TOT indicates that a firm prefers debt financing so that it will be able to earn debt tax shield. As a mode of financing, a firm needs to optimise the costs and benefits of debt and equity financing trade-off, especially bankruptcy cost. At a certain threshold level, the debt tax shield's benefit cannot be absorbed by the cost of debt. Consequently, in achieving an optimal debt level, a firm must 
equalise marginal cost and benefits of debt. The threshold level indicates that there is an inverted U-shape.

The POT indicates that financing cost is directly related with the information asymmetry. A firm can finance its activities from three different sources which include internal fund, debt, and equity. Minimisation of information asymmetry between the managers and shareholders of a firm can be done by following a hierarchy of financial instruments (Zeidan, Galil, \& Shapir, 2018). Generally, a manager knows more about a company's performance, prospects, and risks, as compared to a creditor or a shareholder. In order to compensate for the asymmetric information, an external user such as a creditor will require a higher return to compensate the higher level of risk taken. Essentially, external financing sources will demand a higher rate of return to compensate for higher risk due to the asymmetry. A shareholder generally prefers internally generated fund instead of external financing. It is expected that a shareholder believes that the firm is overvalued when managers use external financing especially new equity. Hence, a shareholder places a lower preference to the issuance of new equity. Debt issuance is preferred relative to the issuance of new equity if there is a need for external financing. On the contrary, debt issuance signals an undervaluation of stock and lesser confidence that the firm believes certain investment are profitable.

The agency cost theory indicates that the objectives of a firm's managers and shareholders differ (Jensen and Meckling, 1976). The differences led to a trade-off between debt and equity level (Miglo, 2016). A manager is expected to maximise his/her utility and the firm's value rather than shareholders' utility. Debt issuance of will reduce agency costs consequently improve a firm's profitability. The issuance of debt controls managers' behaviour to follow shareholders best interests (Grossman and Hart, 1982). To mitigate agency problems, the firms opt for debt financing. Debt is perceived as a discretionary managerial behaviour to ensure that the manager provides a sufficient work effort to optimise a firm's value. Precautionary action must be observed as an excessive use of debt at a certain level may diminish the inherent benefits to the firm and can increase bankruptcy and liquidation possibility. Capital structure market timing theory indicates that a firm monitors market environment in its attempt to take advantage of the market behaviour. A firm will issue new shares if its price is high and the firm will repurchase its own shares when the price is low (Baker and Wurgler, 2002). Hence, the amount of debt or equity to finance activities of a firm is irrelevant, as the firm will choose the type of financing that is optimal at different point of time. These theories suggest that the effect 
of capital structure on firm performance may not be significant and the relationship depends on a myriad of factors. In a perfectly competitive market with full information, capital structure may be irrelevant. However, real world markets are not perfectly competitive and hence capital structure may be important in determining the performance of a firm.

Empirical studies on firms' performance and debt levels have shown to be mixed and different proxies have been used to measure performance fSimerly and Li, 2000; San and Teh, 2011; Khan, 2012; Vithessonthi and Tongurai, 2015; Yazdanfar and Öhman, 2015). Analysis of 39 countries at different levels of economic development showed that firms' performance varies with their legal origin, financial structure, and a level of economic development (González, 2013). Debt negatively affects average performance in the case of smaller business structures, but the results can be positive if the firms have collateral (Tsuruta, 2017). It has also been shown that a firm's Shariah status may contribute to its performance. Using return of stocks as a performance indicator, Reddy and Fu (2014) showed that return on equity and debt-to-equity ratio are a positively related with returns for both Shariah and non-Shariah compliant firms in the Australian Stock Exchange. This indicates that as the debt value increases, the performance of the firms improves regardless of whether they are Shariah or non-Shariah compliant. The study also showed that Shariah compliant firms tend to perform better than non-compliant firms.

Studies have also examined both a single country and multi-countries settings of the association among firm performance, capital structure, and other characteristics of a firm. Hansen and Wernerfelt (1989) and Lee (2009) for US firms, Asimakopoulos et al (2009) for Greece, Nunes et al. (2009) for Portugal, Glancey (1998) for Scotland and Yazdanfer (2013) for Sweden, linked firm performance with firm-specific human resource determinants, firm's and market characteristics including firm's size, investments, current assets, leverage, sales growth, liquidity and tangibility among others. In a multi-country setting, net working capital, lagged profitability, liquidity, sales, firm size, financial gear, market share, assets mix, and location have been included (Crespo and Clark, 2012 and Goddard et al, 2005). Similarly, the results are mixed. For example, firm size was shown to be positively related with performance by Lee (2009), Asimakopoulos et al, (2009) and Ho and Mohd-Raff (2019). However, the relationship is shown to be negatively related by Goddard et al (2005) but there was no relationship by Glancey (1998) and Crespo and Clark (2012). Liquidity was shown to be positively related by Goddard et al 
(2005) and Crespo and Clark (2012) but no relationship by Nunes et al (2009). In Malaysia's context, Daud et al. (2016) study on publicly listed firms during the period of 1994 to 2007 found that debt level does not influence ROA.

Studies have also compared the performance of Shariah and non-Shariah compliant firms. Albaity and Ahmad (2011) found no relationship for firms in Malaysia, and the similar results were reported for Indonesia by Wooi and Ali (2016), and Setiawan and Oktariza (2013).

It can be deduced from the analysis given above that a firm's decisions on capital structure are affected by myriad of factors, and using one particular theory may not explain and provide a complete picture of how firms are making their decisions and what is the relationship among the variables investigated. Indeed, the different theories on capital structure have different assumptions with regards to the working of the market; consequently, a single theory may not be able to offer a comprehensive view of how and why the financial decisions are made.

\section{Empirical Model and Data}

In measuring the potential effects of 2013 revised SC screening method on firms' performance, this study regresses firms' performance on debt level and some control variables that have been determined to affect the firms' performance by the previous studies. Based on Campello (2006), Coricelli, et al (2012), the empirical model used is:

Return $_{\mathrm{it}}=\beta_{0}+\beta_{1} \operatorname{Debt}_{\mathrm{it}}+\beta_{2} \operatorname{Debt}_{\mathrm{it}}^{2}+\beta_{3} \operatorname{Debt}_{\mathrm{it}}^{3}+\beta_{4}$ Tang $_{\mathrm{it}}+\beta_{5}$ Grow $_{\mathrm{it}}+\beta_{6}$ Size $_{\mathrm{it}}+$ $\beta_{7}$ score $_{\text {it }}+\beta_{8} N D T S_{\mathrm{it}}+\beta_{9} H H_{\mathrm{it}}+\beta_{10}$ Inf $_{\mathrm{t}}+\beta_{11} G D P_{\mathrm{t}}+\beta_{12}$ Crisis $_{\mathrm{t}}+\varepsilon_{\mathrm{it}}(1)$

where Return is a measure for firm performance, Debt is the amount of debt. It is measured using the ratio of total liabilities to total assets, $D e b t^{2}$ is the square of Debt level and $D e b t^{3}$ is the cubic of Debt. The square and cubic of debt are included to measure the potential threshold effect and non-monotone effect of debt. As suggested by the different theories discussed earlier, the effect of debt on firm performance is undetermined. The frequently used variables in the study of firm performance are taken as the control variables in the analysis. These variables include structure of tangible asset (Tang) measured using the ratio of fixed assets to total assets, firm's growth opportunity (Grow) measured using the annual percentage change in a firm's sales, firm size (Size) measured using the natural $\log$ of the book value of the total assets; bankruptcy risk (Zscore) is measured using Altman $z$-score (Altman, 1973). The score uses 
different balance sheet values to indicate the financial viability of a firm and it is normally used to forecast bankruptcy. Non-debt tax shield (NDTS) is measured using the ratio of annual depreciation expenses to total asset; industry concentration index $(\mathrm{HH})$ is measured using Herfindal-Hirschman industry concentration index and macroeconomic variables which include inflation rate (Inf), gross domestic product (GDP), and a dummy for 2008 crisis (Crisis). Table 2 further describes the variables used.

\subsection{Firm Performance}

There are a number of proxies to indicate the firm performance. Generally, financial ratio such as return on assets (ROA), return on investment (ROI), and return on equity (ROE) (see Crespo and Clark, 2012; Yazdanfar, 2013) have been used. Other measures of firms' performance include share value (Makhija, 2003), net income to assets ratio (Lee, 2009), and profit-cost margin (McDonald, 1999). This study uses ROA, ROI and ROE. They are the most commonly used performance measures (Zeitun and Tian, 2007). ROA describes how much profit the firm's asset base is able to produce (Banks, 2007). The higher a firm's ROA, the more profit generated from its assets. ROI measures investment return of a firm's capital. According to Otley (2007), ROI is an organisational objective together with profit and economic value added. The higher the ROI, the more positively the firm is perceived as this symbolises efficient use of the capital to generate profit from investments. The ROE measures the amount of profit a firm's equity base is able to produce (Banks, 2007). Similar to ROA and ROI, an increase in ROE, indicates better firm performance as it signifies efficient use of equity to generate profits.

\subsection{Firm Performance}

Studies showed that the effect of asset tangibility on firms' performance varies. Two different relationships can be expected on the affect asset tangibility on performance. A firm with more tangible assets is expected to have smaller costs of financial distress as the assets are easier to monitor, provide good collateral, and tend to reduce agency conflicts (Hull \& Dawar, 2014). A firm with more tangible assets has more flexibility in making decisions; hence the relationship between the firms' tangible assets and performance is expected to be positive. However, tangibility and performance can be negatively related as the assets are related with high investment opportunities especially in the long term (Nunes et al., 2009).

Growth opportunity of a firm is expected to be positively related with the performance as growth opportunity affects a firm's ability to gain opportunities for beneficial investment (Asimakopoulos et al, 2009). 
The relationship between the firm size and performance is also undetermined. Economies of scale help large firms to have better capital markets access (Titman and Wessels, 1988) and large firm may also block entrance for the new comers (Nunes et al, 2009). Furthermore, usually large firms are better-managed, have a larger risk tolerance, and are more diversified; Whereas the smaller firms will find it harder to discover a solution to the information asymmetry problem, and hence they perform worse than the larger firms (Bottazzi and Secchi, 2003; Yasuda, 2005; Zhou and de Wit, 2009). Smaller firms are also sensitive to economic cycles as they have smaller liquidity (Fort et al., 2013). Nevertheless, larger firms might have greater managerial issues and differences between managers and shareholders which can reduce revenue and profit (Pi and Timme, 1993).

Default risk is expected to affect a firm's performance negatively. High risk firms are expected to have higher probability of having managerial issues thus having smaller earnings potential. Low credit risk firms normally are more transparent and have more mature operating and controlling systems, thus having better earnings potentials (Li et al., 2019).

Non-debt tax shields are tax-deductible expenses providing similar benefits to interest expenses from debt financing. The tax shields may include items such as research and development expenses, depreciation and investment tax credit. These items reduce the possibility that a firm would have to incur more debt. Previous empirical findings on the relationship between NDTS and leverage are, however, mixed.

The level of market competitiveness is expected to affect the firm's performance negatively. A monopoly firm, for example, has the market power to limit entry and control prices thus it induces higher returns, similarly for the firms in an oligopolistic market. Furthermore, as oligopolistic firms have experience in enforcing discipline among each other in controlling price, they are expected unlikely to experience losses in times of falling demand. (Slade, 2004; Peress, 2010). Heightened competition limits firm's profits as the competition reduces price level to minimum average total cost.

Three common macroeconomic variables i.e., inflation, GDP, and the 2008 Global economic crisis are included to control the effect of macroeconomic conditions. A firm's performance is expected to depend on a country's economic conditions. An increase in GDP is expected to increase the demand for products 
and services thus improving the firm's performance and vice versa. Changes in GDP may also affect inflation and deflation. Furthermore, inflation may also impact the decision making of firms, consumers, and government. For example, banks may adjust their lending decision as inflation affects opportunity cost and base line interest rates that may affect profit sharing rate. Similarly, firms may also alter their decision with regards to using internally generated or external sources to finance new investments with the changes in inflation and real interest rate. Finally, global economic crisis in 2008 is expected to reduce demand and the firm's performance.

\section{Data}

The firms included in the panel data regression are those that are consistently Shariah-approved for the 15 years period from 2000 to 2014 as listed by the SC. The sectors included were consumer, construction, plantation, industrial, technology, property, trading, and services. This study excludes financial institutions because they are bound by a specific set of rules and regulations established by relevant authorities such as Central Bank of Malaysia. All firms' specific and industry data are sourced from DataStream database, while macroeconomic data are sourced from the World Bank World Development Indicators.

The firms included in the study are the firms that are consistently Shariah-approved since 2014. Several steps are taken to produce the consistently Shariah-approved firms. Firstly, Shariah-approved firms, as published by the SC in November 2014, were used to produce the preliminary list. The second step involved a backward induction process where the Shariahapproved status is identified for every firm until 2000. This is crucial as this study needed 15 years to evaluate the Shariah status of all the firms individually. The backward induction process indicates that only 239 firms remained after screening compared to the original 586 Shariah-approved firms in 2014 .

\section{Analyses and Results}

The descriptive statistics are reported in Table 2. Mean ROA is $4.21 \%$ with a minimum of $-43.22 \%$ and a maximum of $36.50 \%$. Mean ROI is $5.30 \%$ and ranges from $-87.65 \%$ to $71.88 \%$. The mean for $\mathrm{ROE}$ is $4.09 \%$. The range for debt ratio, the main variable of interest, is large with a $0 \%$ minimum and $247.2 \%$ maximum; the mean is $19.7 \%$. Sixty Shariah-approved firms operated with zero debt during the period and eight observations with debt ratio of more than $100 \%$ even after outliers were removed using the Cook's distance test. Three 
alternatives were considered to treat the extreme values: to keep, trim, and Winsorise the extreme values. Examination of annual reports shows that these firms assumed more term loan due to corporate debt restructuring. This suggests that there were firms facing financial difficulties during the period and chose to restructure their finance to maintain their business sustainability and to comply with Bursa Malaysia's trading requirements.

Table 4.1: Descriptive Statistics

\begin{tabular}{|l|c|c|c|c|c|}
\hline & Mean & Standard Deviation & Min & Max & Obs. \\
\hline TD & 0.197 & 0.164 & 0.000 & 2.472 & 3324 \\
\hline ROA & 0.042 & 0.070 & -0.432 & 0.365 & 3324 \\
\hline ROI & 0.053 & 0.096 & -0.876 & 0.719 & 3182 \\
\hline ROE & 0.040 & 0.431 & -22.342 & 2.460 & 3299 \\
\hline PROF & 0.042 & 0.075 & -0.422 & 0.447 & 3277 \\
\hline TANG & 0.407 & 0.200 & 0.000 & 0.987 & 3277 \\
\hline GROW & 0.084 & 0.395 & -0.746 & 12.201 & 3277 \\
\hline SIZE & 5.303 & 0.623 & 3.054 & 7.678 & 3277 \\
\hline Z-SCORE & 1.293 & 0.990 & -3.181 & 4.874 & 3277 \\
\hline NDTS & 0.028 & 0.021 & 0.000 & 0.156 & 3277 \\
\hline HH & 0.079 & 0.039 & 0.035 & 0.270 & 3277 \\
\hline
\end{tabular}




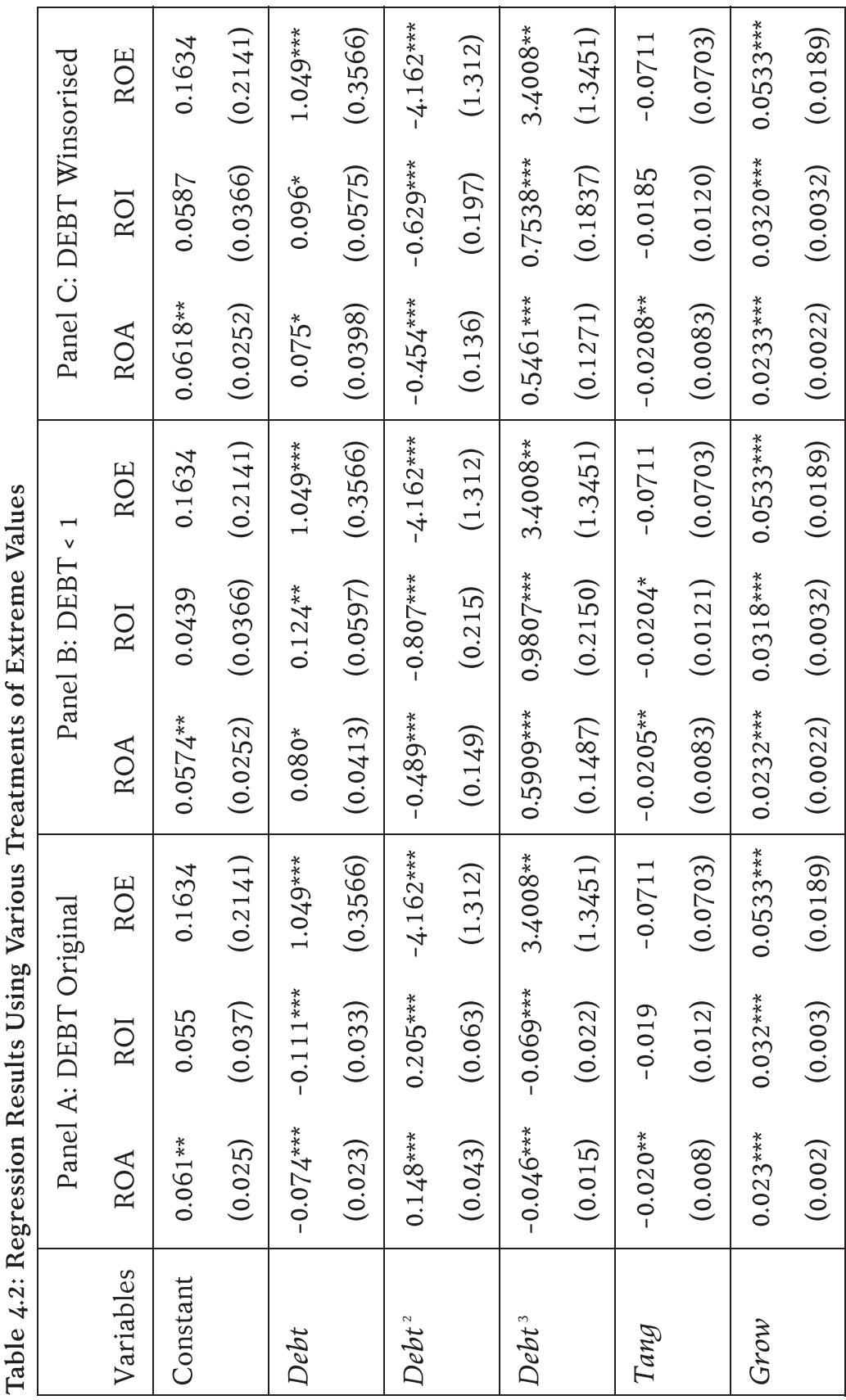




\begin{tabular}{|c|c|c|c|c|c|c|c|c|c|c|c|c|c|c|c|c|}
\hline $\begin{array}{l}\stackrel{*}{n} \\
\hat{0} \\
0 \\
0 \\
i\end{array}$ & $\begin{array}{l}\text { तิ } \\
0 \\
0 \\
0 \\
\dot{0}\end{array}$ & \begin{tabular}{l}
\multirow{*}{*}{} \\
\multirow{*}{*}{} \\
$\stackrel{+}{+}$ \\
$\stackrel{ \pm}{*}$ \\
$\stackrel{0}{0}$
\end{tabular} & $\begin{array}{l}\overparen{b} \\
\ddot{0} \\
\dot{0}\end{array}$ & \begin{tabular}{l}
$\stackrel{0}{N}$ \\
\multirow{N}{N}{} \\
0
\end{tabular} & $\begin{array}{l}\text { के } \\
\infty \\
10 \\
0 \\
0\end{array}$ & $\begin{array}{l}\text { g } \\
\circ \\
\text { v } \\
0 \\
1\end{array}$ & $\begin{array}{l}\text { त̃ } \\
\text { in } \\
\text { in } \\
0 \\
0\end{array}$ & $\begin{array}{l}m \\
0 \\
0 \\
0 \\
0\end{array}$ & $\begin{array}{l}\text { ๓̄ } \\
\text { ᄋ̆ } \\
0 \\
\dot{0}\end{array}$ & $\begin{array}{l}* \\
* \\
\bullet \\
ٌ \\
0 \\
0 \\
0\end{array}$ & $\begin{array}{l}\overparen{N} \\
\tilde{0} \\
0 \\
0 \\
\dot{0}\end{array}$ & 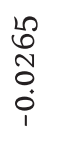 & 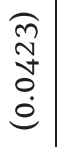 & $\begin{array}{l}\text { ने } \\
\text { N } \\
\text { mे }\end{array}$ & $\begin{array}{l}0 \\
i n \\
0 \\
0\end{array}$ & $\stackrel{\text { }}{\sim}$ \\
\hline \begin{tabular}{l}
$*$ \\
\multirow{2}{*}{} \\
0 \\
$\vdots$ \\
0 \\
$\dot{0}$ \\
1
\end{tabular} & $\begin{array}{l}\text { } \\
0 \\
0 \\
0 \\
\dot{0}\end{array}$ & \begin{tabular}{l}
$*$ \\
\multirow{2}{*}{} \\
$*$ \\
0 \\
0 \\
0 \\
0 \\
0
\end{tabular} & $\begin{array}{l}\text { Ñ } \\
\text { O } \\
0 \\
\dot{\Theta}\end{array}$ & $\begin{array}{l}\text { * } \\
\text { مे } \\
\text { ने } \\
\stackrel{-}{0} \\
1\end{array}$ & $\begin{array}{l}\overparen{N} \\
\stackrel{n}{\beth} \\
\overrightarrow{0}\end{array}$ & $\begin{array}{l}\stackrel{*}{\wedge} \\
\stackrel{9}{+} \\
\stackrel{-}{0} \\
\dot{0}\end{array}$ & $\begin{array}{c}6 \\
0 \\
1 \\
0 \\
0 \\
\dot{0}\end{array}$ & $\begin{array}{l}-1 \\
\bar{\circ} \\
\circ \\
\dot{0}\end{array}$ & $\begin{array}{l}6 \\
0 \\
0 \\
0 \\
0\end{array}$ & $\begin{array}{l}1 \\
0 \\
0 \\
0 \\
0\end{array}$ & $\begin{array}{l}6 \\
\circ \\
\circ \\
0 \\
0 \\
0\end{array}$ & $\begin{array}{l}\infty \\
\text { N } \\
O \\
0 \\
0\end{array}$ & $\begin{array}{l}\text { ñ } \\
0 \\
0 \\
0 \\
0\end{array}$ & $\begin{array}{l}\mathcal{N} \\
\infty \\
\hat{n}\end{array}$ & 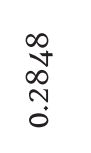 & $\stackrel{\text { }}{\sim}$ \\
\hline 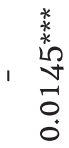 & $\begin{array}{l}\text { I্ } \\
\text { ○े } \\
0 \\
\dot{0}\end{array}$ & 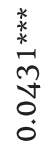 & $\begin{array}{l}\text { ब̄ } \\
0 \\
\circ \\
\dot{0}\end{array}$ & $\begin{array}{l}* \\
\stackrel{*}{-} \\
\\
\overrightarrow{0} \\
i\end{array}$ & $\begin{array}{l}\text { ñ } \\
N \\
0 \\
\dot{0}\end{array}$ & $\begin{array}{l}* \\
* \\
\infty \\
10 \\
= \\
-1 \\
0 \\
0\end{array}$ & $\begin{array}{l}\hat{20} \\
\infty \\
10 \\
0 \\
\dot{0}\end{array}$ & 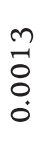 & $\begin{array}{l}\text { İ } \\
\overline{0} \\
\circ \\
\dot{0}\end{array}$ & $\begin{array}{l}\searrow \\
O \\
\circ \\
\circ \\
\dot{0}\end{array}$ & $\begin{array}{l}\text { ঠे } \\
\circ \\
\circ \\
0 \\
\dot{0}\end{array}$ & $\begin{array}{l}-1 \\
0 \\
0 \\
0 \\
0\end{array}$ & $\begin{array}{l}0 \\
10 \\
0 \\
0 \\
0 \\
0\end{array}$ & $\begin{array}{l}\stackrel{N}{ } \\
\text { mे } \\
\text { nे }\end{array}$ & 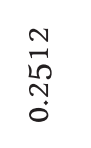 & શે \\
\hline $\begin{array}{l}\stackrel{*}{n} \\
\hat{0} \\
0 \\
0 \\
1\end{array}$ & $\begin{array}{l}\text { ত̃ } \\
0 \\
0 \\
0 \\
\dot{0}\end{array}$ & $\begin{array}{l}\stackrel{*}{*} \\
\stackrel{*}{*} \\
\stackrel{y}{+} \\
\stackrel{+}{*} \\
\vdots \\
0\end{array}$ & $\begin{array}{l}00 \\
0 \\
0 \\
0 \\
0\end{array}$ & 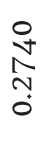 & $\begin{array}{l}0 \\
\infty \\
0 \\
0 \\
0\end{array}$ & \begin{tabular}{l} 
g \\
O \\
\multirow{2}{0}{} \\
$i$ \\
1
\end{tabular} & $\begin{array}{l}\text { Ñ } \\
\text { in } \\
i n \\
0 \\
0\end{array}$ & $\begin{array}{l}m \\
0 \\
-1 \\
0 \\
0\end{array}$ & $\begin{array}{l}\text { ๓̄ } \\
\text { ஜ } \\
0 \\
\dot{0}\end{array}$ & \begin{tabular}{l}
$*$ \\
\multirow{2}{*}{} \\
$\emptyset$ \\
0 \\
0 \\
0
\end{tabular} & $\begin{array}{l}\overparen{N} \\
\tilde{O} \\
0 \\
0 \\
0\end{array}$ & $\begin{array}{l}10 \\
0 \\
N \\
0 \\
0 \\
1\end{array}$ & \begin{tabular}{l}
$\overparen{n}$ \\
\multirow{v}{*}{} \\
0 \\
$\dot{0}$
\end{tabular} & $\begin{array}{l}\text { શે } \\
\text { N } \\
\text { mे }\end{array}$ & $\begin{array}{l}0 \\
\hat{1} \\
0 \\
0\end{array}$ & ๗ે \\
\hline $\begin{array}{l}\text { in } \\
\text { ñ } \\
0 \\
0 \\
\dot{0} \\
1\end{array}$ & $\begin{array}{l}\text { बे } \\
0 \\
0 \\
0\end{array}$ & 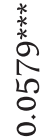 & $\begin{array}{l}\text { O) } \\
\text { N } \\
0 \\
0 \\
\dot{0}\end{array}$ & $\begin{array}{l}\overrightarrow{0} \\
\text { م0 } \\
0 \\
1 \\
1\end{array}$ & $\begin{array}{l}\overparen{N} \\
\stackrel{m}{二} \\
\stackrel{0}{0}\end{array}$ & \begin{tabular}{l}
$*$ \\
\multirow{2}{*}{} \\
$\circ$ \\
0 \\
$\infty$ \\
-1 \\
0
\end{tabular} & $\begin{array}{l}0 \\
10 \\
\infty \\
0 \\
0 \\
0\end{array}$ & 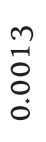 & $\begin{array}{l}6 \\
0 \\
0 \\
0 \\
0\end{array}$ & $\begin{array}{l}\hat{O} \\
\circ \\
\circ \\
0\end{array}$ & $\begin{array}{l}\text { In } \\
0 \\
0 \\
0 \\
\dot{0}\end{array}$ & $\begin{array}{l}10 \\
1 \\
0 \\
0 \\
0\end{array}$ & $\begin{array}{l}\text { Nิ } \\
\text { O } \\
0 \\
\dot{0}\end{array}$ & $\begin{array}{l}N \\
\hat{N}\end{array}$ & $\begin{array}{l}\stackrel{0}{N} \\
\stackrel{N}{N} \\
0\end{array}$ & $\stackrel{\text { }}{\text { N }}$ \\
\hline $\begin{array}{r}* \\
* \\
* \\
0 \\
1 \\
1 \\
0 \\
0 \\
0\end{array}$ & 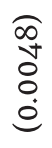 & 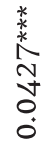 & $\begin{array}{l}\sigma \\
\check{0} \\
0 \\
\dot{0}\end{array}$ & $\begin{array}{l}\stackrel{0}{a} \\
\stackrel{N}{ } \\
\stackrel{0}{0} \\
1\end{array}$ & $\begin{array}{l}\hat{N} \\
\hat{N} \\
0 \\
\dot{0}\end{array}$ & $\begin{array}{l}* \\
* \\
0 \\
0 \\
+ \\
N \\
- \\
0 \\
0\end{array}$ & $\begin{array}{l}\text { क } \\
\infty \\
10 \\
0 \\
\dot{0}\end{array}$ & 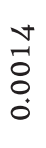 & $\begin{array}{l}\text { בิ } \\
0 \\
0 \\
0 \\
0\end{array}$ & $\begin{array}{l}\searrow \\
\stackrel{+}{0} \\
0 \\
0 \\
0\end{array}$ & $\begin{array}{l}\text { ఫે } \\
\circ \\
O \\
0 \\
\dot{0}\end{array}$ & $\begin{array}{l}1 \\
0 \\
0 \\
0 \\
0 \\
1\end{array}$ & $\begin{array}{l}0 \\
\text { 엉 } \\
0 \\
0 \\
\dot{0}\end{array}$ & $\begin{array}{l}0 \\
m \\
m \\
m\end{array}$ & 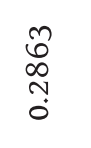 & શે \\
\hline $\begin{array}{l}\stackrel{*}{n} \\
\hat{0} \\
0 \\
\dot{1}\end{array}$ & $\begin{array}{l}\text { ত̃ } \\
0 \\
0 \\
0 \\
\dot{0}\end{array}$ & \begin{tabular}{l}
$\stackrel{*}{*}$ \\
\multirow{*}{*}{} \\
$\stackrel{y}{+}$ \\
$\stackrel{+}{*}$ \\
$\vdots$ \\
0
\end{tabular} & $\begin{array}{l}\text { ठ0 } \\
\ddot{0} \\
0 \\
0\end{array}$ & \begin{tabular}{l}
$\stackrel{0}{N}$ \\
\multirow{N}{*}{} \\
0
\end{tabular} & $\begin{array}{l}\text { के } \\
\infty \\
10 \\
0 \\
0\end{array}$ & $\begin{array}{l}\text { g } \\
\text { ᄋ } \\
\text { N. } \\
\dot{0}\end{array}$ & 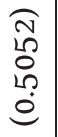 & $\begin{array}{l}m \\
0 \\
0 \\
0 \\
0\end{array}$ & $\begin{array}{l}\text { กิ } \\
\text { ळे } \\
0 \\
\dot{0}\end{array}$ & \begin{tabular}{l}
$*$ \\
\multirow{*}{*}{} \\
$\emptyset$ \\
0 \\
0 \\
0
\end{tabular} & $\begin{array}{l}\text { Nิ } \\
\text { Oे } \\
0 \\
\dot{0}\end{array}$ & 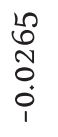 & \begin{tabular}{l}
$\overparen{n}$ \\
\multirow{1}{*}{} \\
0 \\
0 \\
$\dot{0}$
\end{tabular} & $\begin{array}{l}\text { مे } \\
\text { ஸे }\end{array}$ & $\begin{array}{l}0 \\
\hat{\imath} \\
0 \\
0 \\
0\end{array}$ & ๗ે \\
\hline $\begin{array}{l}n_{n}^{*} \\
\sigma \\
0 \\
1\end{array}$ & $\begin{array}{l}\text { T⿱丶万仒 } \\
0 \\
\dot{0}\end{array}$ & $\begin{array}{l}* \\
* \\
\infty \\
1 \\
1 \\
0 \\
0\end{array}$ & $\begin{array}{l}\text { กิ } \\
0 \\
0 \\
0\end{array}$ & 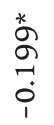 & $\begin{array}{l}\overparen{J} \\
\stackrel{-}{-} \\
\dot{0}\end{array}$ & $\begin{array}{l}m \\
\stackrel{m}{0}\end{array}$ & 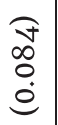 & $\begin{array}{l}-1 \\
\circ \\
\circ \\
0\end{array}$ & 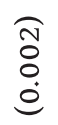 & $\begin{array}{l}\tilde{0} \\
0 \\
0\end{array}$ & $\begin{array}{l}\text { Oे } \\
0 \\
0 \\
\dot{0}\end{array}$ & $\begin{array}{l}\text { ON } \\
0 \\
0 \\
0\end{array}$ & $\begin{array}{l}\text { I } \\
0 \\
0 \\
\dot{0}\end{array}$ & $\begin{array}{l}\infty \\
\infty \\
-1 \\
m\end{array}$ & 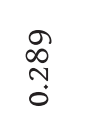 & $\stackrel{\text { సે }}{\sim}$ \\
\hline $\begin{array}{l}* \\
* \\
* \\
m \\
-1 \\
0 \\
\dot{0} \\
1\end{array}$ & $\begin{array}{l}\text { Lิ } \\
0 \\
0 \\
0 \\
0\end{array}$ & \begin{tabular}{l}
$\stackrel{*}{*}$ \\
\multirow{*}{*}{} \\
\multirow{0}{*}{} \\
0 \\
0
\end{tabular} & $\begin{array}{l}\text { তิ } \\
\text { ᄋ } \\
\dot{U}\end{array}$ & $\begin{array}{l}\stackrel{*}{N} \\
\stackrel{-}{-} \\
\stackrel{0}{1}\end{array}$ & $\begin{array}{l}\text { N } \\
0 \\
0\end{array}$ & $\begin{array}{l}\stackrel{*}{n} \\
0 \\
\stackrel{-}{0} \\
0\end{array}$ & $\begin{array}{l}\text { के } \\
\text { ம } \\
0 \\
\dot{0}\end{array}$ & $\begin{array}{l}-1 \\
\\
\circ\end{array}$ & $\begin{array}{l}\overrightarrow{\overrightarrow{0}} \\
0 \\
\dot{0}\end{array}$ & $\begin{array}{l}\circ \\
\circ \\
\circ \\
\dot{0}\end{array}$ & $\begin{array}{l}\text { Oे } \\
0 \\
0 \\
\dot{0} \\
0\end{array}$ & $\begin{array}{l}0 \\
0 \\
0 \\
0 \\
1\end{array}$ & $\begin{array}{l}20 \\
0 \\
0 \\
\dot{0} \\
0\end{array}$ & $\begin{array}{l}\stackrel{v}{N} \\
\text { mे } \\
\text { ñ }\end{array}$ & $\begin{array}{l}\overline{0} \\
\text { n. } \\
0\end{array}$ & ભે \\
\hline$\stackrel{N}{\sim}$ & & 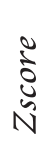 & & $\stackrel{n}{\hat{z}}$ & & $\underset{I}{I}$ & & $\Xi$ & & (ิ) & & $\stackrel{\bar{s}}{s}$ & & $\dot{0}$ & 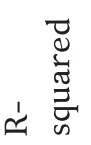 & $\begin{array}{ll} & \\
0 \\
0 \\
\dot{0}\end{array}$ \\
\hline
\end{tabular}


The fixed effect panel regression results are presented in Table 3. Panel A presents the results when the extreme values were included in Panel B and Panel C, the trim and Winsorising methods were used. The results when ROE is the dependent variable are the same across the panel as eight extreme observations in the data set are missing due to non-availability of ROE value.

In Panel $\mathrm{A}$, the results are inconsistent across different performance indicators. Although all performance indicators suggest an S-shaped relationship, the shape of the curve is different from the S-shape especially for the ROE. As for the ROA and ROI, given the sign of Debt, Debt ${ }^{2}$ and $D e b t^{3}$, the curve will concave down and then concave up. In contrast, while using ROE as a performance indicator, the curve is expected to concave up and then concave down.

Figure 1 shows that maintaining the eight extreme value observations in the regression model changes the curve line of the graph so that it is no longer S-shaped, as per the earlier expectation. This indicates that inclusion of the eight extreme value observations is not advisable; hence the trim and Winsorising results are elaborated.

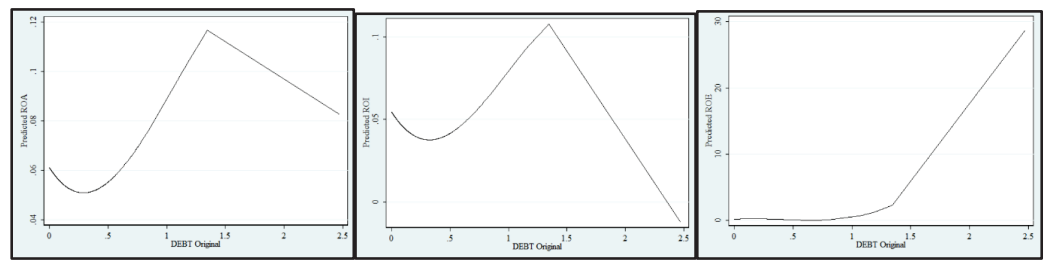

Figure 1: The Impact of Eight Outliers on the Predicted ROA, ROI and ROE

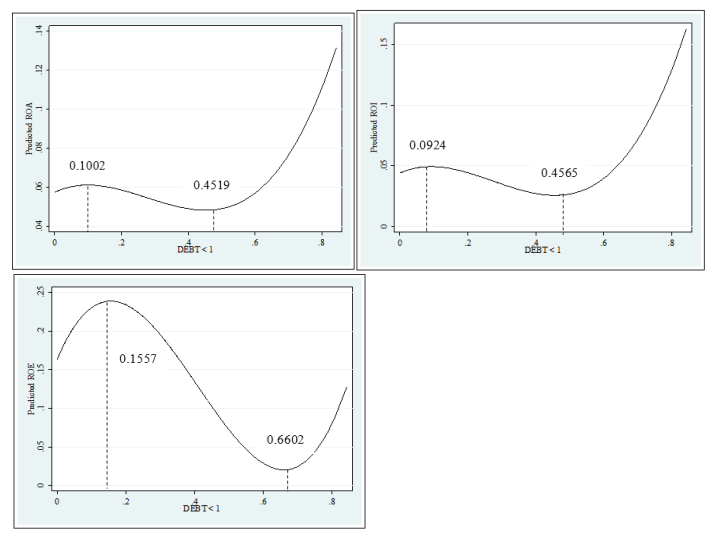

Figure 2: Predicted Firms' Performance Indicator and Debt Level (Trimming) 


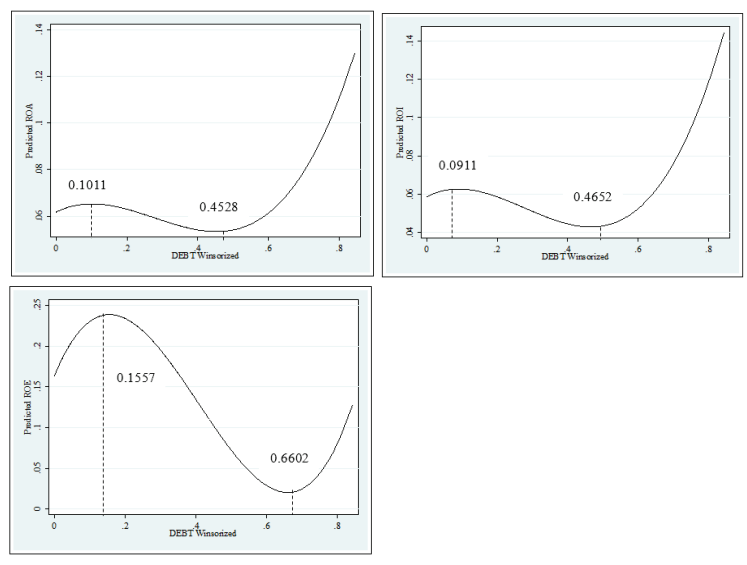

Figure 3: Predicted Firms' Performance Indicator and Debt Level (Winsorising)

Panel B and Panel C show consistent sign for Debt, Debt ${ }^{2}$ and $D e b t^{3}$ using the different performance indicators ROA, ROI and ROE. Both alternatives portray an S-shaped relationship between performance indicator and debt level regardless of different performance indicator. Figures 4.2 and 4.3 illustrate the non-monotonic relationship of the predicted performance indicator and debt level using trimming and Winsorising alternatives respectively, the inflexion point, which determines the point where the curve line changed.

Given the second inflexion point, it can be concluded, using ROA, the performance of Shariah-approved firms will increase if their debt ratio is beyond 45.28\%. Meanwhile, using ROI and ROE, the study finds that the performance of the Shariah-approved firms will increase if the debt ratio is beyond $46.52 \%$ and $66.02 \%$ respectively.

Nevertheless, the results show optimal points of debt ratio for Shariahapproved firms in Malaysia. It partly supports the trade-off hypothesis, which suggests there is a point where debt benefits are no longer equal to debt cost. However, as evidenced by the second inflexion point, it is beyond the SC's debt ratio benchmark which dictates that listed Shariah-approved firms in Malaysia cannot exceed $33 \%$ debt. The results are similar to the previous studies that support the non-monotonic relationship between performance and debt levels 
such as Lin and Chang (2011) and Ahmad and Abdullah (2013). Their direction of the relationship differs from this study. In contrast to our evidence, Lin and Chang (2011) found that a debt ratio threshold of more than $33.33 \%$ did not contribute to the performance of Taiwanese listed firms during the period of 1993 to 2005. Ahmad and Abdullah (2013) had the same finding for Malaysian listed firms at $64.33 \%$ debt ratio threshold.

With regards to the control variables, tangible asset affects ROA negatively. There is a negative relationship between firm size and all three measures of the firm's performance. There is a positive relationship between a firm's growth opportunity and default risk with all three measures of firm performance. The relationship for growth opportunity is as expected; however, the relationship with default risk is not as expected. Unlike expectation, more concentrated industry performs better than less concentrated industry in terms of ROA and ROI. Lastly, the effect of non-debt tax shield and all three macroeconomic measures namely GDP, inflation, and crisis are not significant The empirical evidence indicates that Malaysia's Shariah-approved firms will perform better if their debt level is above the 33\% debt ratio. Thus, the 2013 revised Shariah screening method introducing the $33 \%$ debt ratio benchmark is not expected to improve the performance of the Shariah-approved firms and indexes in Malaysia. Consequently, this raises the question of whether the quantitative benchmark benefits the Shariah-approved firms in Malaysia or not

\section{Conclusion}

Targeting internationalisation and widening of market connectivity, SC of Malaysia revised its Shariah approved firm screening method in November 2013 in order to be in line with global Shariah indexes. The revision requires publicly listed firms in Bursa Malaysia to comply with the 33\% benchmark for both debt and cash ratio, among others, if they are to be Shariah approved. The revision is expected to influence the performance of the Shariah approved firms and indexes as the capital structure has shown to impact the firms' performance. The regression results indicate a non-monotone relationship between firm's performance and debt level of Shariah-approved firms in Malaysia. Nevertheless, the results showed that the introduction of the debt ratio assessment as a part of the revised Shariah screening method would not contribute to improve the performance of the Shariah approved firms. The inflexion point of more than $33 \%$ is beyond the SC's debt ratio requirement in the revised Shariah screening method introduced in 2013. Furthermore, the results also show that the performance of the Shariah approved firms mimics the performance of the conventional firms even though a stringent assessment has been imposed on the Shariah approved firms. 


\section{References}

Ahmad, A. H., \& Abdullah, N. A. H. (2013). Investigation of optimal capital structure in Malaysia: A panel threshold estimation. Studies in Economics and Finance, 30(2), 108-117.

Albaity, M., \& Ahmad, R. (2011). A comparative analysis of the firm specific determinants of Syariah compliant versus non-Syariah compliant firms in Bursa Malaysia. Asian Journal of Business and Accounting, 4(1), 59-84.

Altman, E. I. (1984). A further empirical investigation of the bankruptcy cost question. The Journal of Finance, 39(4), 1067-1089.

Arshad, S., Rizvi, S. A. R., Ghani, G. M., \& Duasa, J. (2016). Investigating stock market efficiency: A look at OIC member countries. Research in international business and finance, 36, 402-413.

Asimakopoulos, I., Samitas, A., \& Papadogonas, T. (2009). Firm-specific and economy wide determinants of firm profitability: Greek evidence using panel data. Managerial Finance, 35(11), 930-939.

Bakar, M. A. A. A., \& Ali, N. (2014). Performance measurement analysis: Shariah-compliant vs. non Shariah-compliant securities. Malaysian Accounting Review, 13(1), 75-108.

Baker, M., \& Wurgler, J. (2002). Market timing and capital structure. The journal of finance, $57(1), 1-32$.

Banks, E. (2007). Finance: The basics (1st Editio). United Kingdom: Routledge.

Berger, A. N., \& Di Patti, E. B. (2006). Capital structure and firm performance: A new approach to testing agency theory and an application to the banking industry. Journal of Banking \& Finance, 30(4), 1065-1102.

Bottazzi, G., \& Secchi, A. (2003). Why are distributions of firm growth rates tent-shaped?. Economics Letters, 80(3), 415-420.

Campello, M. (2006). Debt financing: Does it boost or hurt firm performance in product markets?. Journal of Financial Economics, 82(1), 135-172.

Coricelli, F., Driffield, N., Pal, S., \& Roland, I. (2012). When does leverage hurt productivity growth? A firm-level analysis. Journal of international Money and Finance, 31(6), 1674-1694.

Crespo, G., \& Clark, R. A. (2012). Analyzing the determinants of profitability, Part 3: evidence from European manufacturers. Transfer Pricing Report, 21(6), 297-310.

Daud, W. M. N. W., Norwani, N. M., Mansor, A. A., \& Endut, W. A. (2016). Does financing decision influence corporate performance in Malaysia? International Journal of Economics and Financial Issues, 6(3), 1165-1171.

Fort, T. C., Haltiwanger, J., Jarmin, R. S., \& Miranda, J. (2013). How firms respond to business cycles: The role of firm age and firm size. IMF Economic Review, 61(3), 520-559. 
Glancey, K. (1998). Determinants of growth and profitability in small entrepreneurial firms. International Journal of Entrepreneurial Behavior $\mathcal{E}$ Research, 4(1), 18-27.

Goddard, J., Tavakoli, M., \& Wilson, J. O. S. (2005). „Determinants of profitability in European manufacturing and services: evidence from a dynamic panel model". Applied Financial Economics, 15(18), p. 1269-1282.

González, V. M. (2013). Leverage and corporate performance: International evidence. International Review of Economics and Finance, 25, 169-184.

Grossman, S. J., \& Hart, O. D. (1982). Corporate financial structure and managerial incentives. In The economics of information and uncertainty (pp. 107-140). University of Chicago Press.

Hansen, G. S., \& Wernerfelt, B. (1989). Determinants of firm performance: The relative importance of economic and organizational factors. Strategic management journal, 10(5), 399-411.

Ho, C. S. F. (2015). International comparison of Shari'ah compliance screening standards. International Journal of Islamic and Middle Eastern Finance and Management, 8(2), 222-245.

Ho, C. S., \& Mohd-Raff, N. E. N. (2019). External and internal determinants of performances of Shariah and non-Shariah compliant firms. International Journal of Islamic and Middle Eastern Finance and Management.

Hull, R. M., \& Dawar, V. (2014). Agency theory, capital structure and firm performance: some Indian evidence. Managerial Finance.

Ismail, W. A. W., Kamarudin, K. A., \& Sarman, S. R. (2015). The quality of earnings in Shariah compliant companies: Evidence from Malaysia. Journal of Islamic Accounting and Business Research, 6(1), 19-41.

Jensen, M. C., \& Meckling, W. H. (1976). Theory of the firm: Managerial behavior, agency costs and ownership structure. Journal of Financial Economics, 3(4), 305-360.

Jermias, J. (2008). The relative influence of competitive intensity and business strategy on the relationship between financial leverage and performance. The British Accounting Review, 40(1), 71-86.

Kayo, E. K., \& Kimura, H. (2011). Hierarchical determinants of capital structure. Journal of Banking and Finance, 35(2), 358-371.

Khan, A. G. (2012). The relationship of capital structure decisions with firm performance: A study of the engineering sector of. International Journal of Accounting and Financial Reporting, 2(1), 245-262.

Lazăr, S. (2016). Determinants of firm performance: Evidence from Romanian listed companies. Review of Economic and Business Studies, 9(1), 53-69.

Lee, J. (2009). Does size matter in firm performance? Evidence from US public firms. International Journal of the economics of Business, 16(2), 189-203. 
Li, K., Niskanen, J., \& Niskanen, M. (2019). Capital structure and firm performance in European SMEs: Does credit risk make a difference?. Managerial Finance, 45(5), 582-601.

Lin, F.-L., \& Chang, T. (2011). Does debt affect firm value in Taiwan? A panel threshold regression analysis. Applied Economics, 43(1), 117-128.

Makhija, M. (2003). Comparing the resource-based and market-based views of the firm: empirical evidence from Czech privatization. Strategic management journal, 24(5), 433-451.

McDonald, J. T. (1999). The determinants of firm profitability in Australian manufacturing. Economic Record, 75(2), 115-126.

McNamara, R., \& Duncan, K. (1995). Firm performance and macroeconomic variables. Bond University School of Business discussion papers. Paper no. 66.

Miglo, A. (2016). Capital structure in the modern world. Springer.

Modigliani, F., \& Miller, M. H. (1958). The cost of capital, corporation finance and the theory of investment. American Economic Review, 48(3), 261-297.

Nunes, P. J. M., Serrasqueiro, Z. M., \& Sequeira, T. N. (2009). Profitability in Portuguese service industries: a panel data approach. The Service Industries Journal, 29(5), 693-707.

Otley, D. (2007). Accounting performance measurement: A review of its purposes and practices. In A. Neely (Ed.), Business performance measurement: Unifying theories and integrating practice (2nd Editio, p. 511). New York: Cambridge University Press.

Peress, J. (2010). Product market competition, insider trading, and stock market efficiency. Journal of Finance, 65(1), 1-43.

Pi, L., \& Timme, S. G. (1993). Corporate control and bank efficiency. Journal of Banking E Finance, 17(2-3), 515-530.

Pok, W.C. (2012). Analysis of Syariah quantitative screening norms among Malaysia Syariah-compliant stocks. Investment Management and Financial Innovations, 9(2), 69-80.

Reddy, K., \& Fu, M. (2014). Does Shariah compliant stocks perform better than the conventional stocks? A comparative study stocks listed on the Australian stock exchange. Asian Journal of Finance and Accounting, 6(2), 155-170.

San, O. T., \& Teh, B. H. (2011). Capital structure and corporate performance of Malaysian construction sector. International Journal of Humanities and Social Science, 1(2), 28-36.

Securities Commission Malaysia. (2013). Revised Shariah screening methodology: Expands ICM's global reach. Securities Commission Malaysia, 
36. Retrieved from https://www.sc.com.my/wp-

content/uploads/eng/html/icm/13_02_12_msianicm.pdf

Setiawan, C., \& Oktariza, H. (2013). Syariah and conventional stocks performance of public companies listed on Indonesia Stock Exchange. Journal of Accounting, Finance and Economics, 3(1), 51-64.

Simerly, R. L., \& Li, M. (2000). Environmental dynamism, capital structure and performance: A theoretical integration and an empirical test. Strategic Management Journal, 21(1), 31-49.

Slade, M. E. (2004). Competing models of firm profitability. International Journal of Industrial Organization, 22(3), 289-308.

Titman, S., \& Wessels, R. (1988). The determinants of capital structure choice. The Journal of finance, 43(1), 1-19.

Tsuruta, D. (2017). Variance of firm performance and leverage of small businesses. Journal of Small Business Management, 55(3), 329-502.

Vithessonthi, C., \& Tongurai, J. (2015). The effect of firm size on the leverageperformance relationship during the financial crisis of 2007-2009. Journal of Multinational Financial Management, 29(1), 1-29.

Wooi, H. C., \& Ali, R. (2017). Does Muslim CEO Matters in Shariah compliant companies? Evidence from listed firms in Malaysia. Pacific-Basin Finance Journal, 42(C), 126-141.

Yasuda, T. (2005). Firm growth, size, age and behavior in Japanese manufacturing. Small Business Economics, 24(1), 1-15.

Yazdanfar, D. (2013). Profitability determinants among micro firms: evidence from Swedish data. International Journal of Managerial Finance, 9(2), 151160.

Yazdanfar, D., \& Öhman, P. (2015). Debt financing and firm performance: An empirical study based on Swedish data. The Journal of Risk Finance, 16(1), 102-118.

Zeidan, R., Galil, K., \& Shapir, O. M. (2018). Do ultimate owners follow the pecking order theory?. The Quarterly Review of Economics and Finance, 67, 45-50.

Zeitun, R., \& Tian, G. (2007). Capital structure and corporate performance: Evidence from Jordan. Australasian Accounting Business and Finance Journal Capital, 1(4).

Zhou, H., \& de Wit, G. (2009). Determinants and dimensions of firm growth. SCALES EIM Research Reports (H200903). 